\title{
QTLs for resistance to soybean cyst nematode, races 3, 9, and 14 in cultivar Hartwig
}

\author{
Marcia Flores da Silva Ferreira(1), Gerardo Domingo Lucio Cervigni(2), Adésio Ferreira ${ }^{(1)}$, Ivan Schuster ${ }^{(3)}$, \\ Fernanda Abreu Santana ${ }^{(4)}$, Waldir Dias Pereira ${ }^{(5)}$, Everaldo Gonçalves de Barros ${ }^{(4)}$ and Maurilio Alves Moreira(4) \\ (1)Universidade Federal do Espírito Santo, Centro de Ciências Agrárias, Departamento de Produção Vegetal, Alto Universitário, s/no, Caixa \\ Postal 16, CEP 29500-000 Alegre, ES, Brazil. E-mail: marciaflores@cca.ufes.br, adesioferreira@gmail.com ${ }^{(2)}$ Centro de Estudios Fotosintéticos \\ y Bioquímicos, Suipacha 531, 2000, Rosario, Santa Fe, Argentina. E-mail: cervigni@cefobi-conicet.gov.ar ${ }^{(3)}$ Cooperativa Central de Pesquisa \\ Agrícola, BR 467, Km 98, Caixa Postal 301, CEP 85813-450 Cascavel, PR, Brazil. E-mail: ivan@coodetec.com.br (4)Universidade Federal de \\ Viçosa, Instituto de Biotecnologia Aplicada à Agropecuária, Avenida P. H. Rolfs, s/no, CEP 36570-000 Viçosa, MG, Brazil. E-mail: ebarros@ufv.br, \\ moreira@ufv.br, fsantana_ufv@yahoo.com.br (5)Embrapa Soja, Caixa Postal 231, CEP 86001-970 Londrina, PR, Brazil. E-mail: dias@cnpso.embrapa.br
}

\begin{abstract}
The objective of this work was to identify major and minor-effect quantitative trait loci (QTL) for resistance to races 3, 9, and 14 of soybean cyst nematode (SCN) in Hartwig cultivar; to map new resistance QTLs for these races; and to check for the existence of epistatic interactions between QTLs. Cultivar Hartwig is an important resistance source to SCN. Recombinant inbred lines (RIL) obtained from a cross between 'Hartwig' (resistant) and Y23 (susceptible) were evaluated regarding resistance to the three races. New genomic regions for resistance to SCN were identified by microsatellites. Four QTLs, which explained between 12 and $34 \%$ of phenotypic variance, were detected for resistance to race 3 in linkage groups (LG) A2, G, J, and M. The QTL in LG G is also important for resistance to race 9. Epistatic interactions were detected between loci, which indicate resistance to races 9 and 14. There are high and low-effect resistance QTLs to SCN.

Index terms: Glycine max, breeding, marker-assisted selection, molecular markers.

\section{QTLs de resistência ao nematoide do cisto da soja, raças 3, 9 e 14 na cultivar Hartwig}

Resumo - O objetivo deste trabalho foi identificar locos associados a características quantitativas (QTL) de efeito maior e menor para a resistência às raças 3, 9 e 14 do nematoide do cisto da soja (NCS) na cultivar Hartwig, mapear novos QTLs de resistência para estas raças e verificar a existência de interações epistáticas entre QTLs. A cultivar Hartwig é uma importante fonte de resistência ao NCS. Linhagens endogâmicas recombinantes (LER) obtidas do cruzamento entre 'Hartwig' (resistente) e Y23 (suscetível) foram avaliadas quanto à resistência às três raças. Novas regiões genômicas de resistência ao NCS foram identificadas por microssatélites. Quatro QTLs, que explicaram entre 12 e 34\% da variância fenotípica, foram detectados para a resistência à raça 3 nos grupos de ligação (GL) A2, G, J e M. O QTL no GL G também é importante para a resistência à raça 9. Interações epistáticas foram detectadas entre loci, o que indica resistência às raças 9 e 14 . Há QTLs de maior e menor efeito para a resistência ao NCS.

Termos para indexação: Glycine max, melhoramento, seleção assistida por marcadores, marcadores moleculares.

\section{Introduction}

More than 15 years of QTL mapping for resistance to soybean cyst nematode (SCN) are justified by losses in soybean production (Winter et al., 2006), diversity of the pathogen (Niblack et al., 2002), and limitations on phenotypic evaluation, such as cost, time and environmental influence. Resistant cultivars associated with nonhost crops are the main method for controlling $\mathrm{SCN}$. In breeding programs, marker-assisted selection is an important tool for the selection of resistant lines, reducing the number of lines for assessment in the greenhouse (Concibido et al., 2004; Dias et al., 2009).

QTLs for resistance to several SCN races have been identified in almost all soybean chromosomes and in different resistance sources (Concibido et al., 2004). The number of resistance genes varies depending on the source (Concibido et al., 2004; Dias et al., 2009). Two major genes, rhgl, from linkage group (LG) G, and Rhg4, from LG A2, are well-known. Several 
minor resistance genes have also been reported, whose importance varies according to germplasm and nematode race (Winter et al., 2006).

The rhgl gene, which is vital for broad resistance to $\mathrm{SCN}$, has been detected in various resistance sources and in cultivars Hartwig and Peking (Concibido et al., 2004; Guo et al., 2006). Resistance alleles have also been described in the rhgl locus in plant introductions (PI) 437654 and 88788 (Brucker et al., 2005). The Rhg4 gene is important for resistance to race 3 (Webb et al., 1995; Concibido et al., 2004). However, PI 464925B does not harbor rhgl or Rhg4, but is resistant to SCN races 3 and 2 (Winter et al., 2006). It was recently reported that QTLs in LG B1 and I are important for broad resistance to SCN (Wu et al., 2009). In general, studies on QTL mapping have low-consistency information on minor QTLs, which is unlikely to be confirmed in independent studies (Concibido et al., 2004; Winter et al., 2006). Nevertheless, epistatic interactions between major and minor QTLs are important for resistance to several races (Wu et al., 2009).

Among the sources of SCN resistance, PI 437654 is one of the most studied (Concibido et al., 2004). This PI is a parent of cultivar Hartwig, frequently used in Brazilian soybean breeding programs, and is resistant to almost all SCN races, except races $4^{+}$and $14^{+}$(Dias et al., 2009). QTLs in LGs A2, B1, C1, G, J, H, K, D1a, and $\mathrm{I}$ for resistance to $\mathrm{SCN}$ races 1, 2, 3, 5, and 14 were also reported (Wu et al., 2009). In 'Hartwig', QTLs were identified in LGs A2, B1, and F for resistance to race 3 (Vierling et al., 1996); in LG D2 for resistance to race 14 (Schuster et al., 2001); and in LG G (rhgl) for resistance to races 3 and 9 (Cervigni et al., 2007). Kazi et al. (2010) reported that in 'Hartwig' the rhgl locus shows resistance to races 2,3 , and 14 . The authors also observed QTL resistance to race 2 in LG D2 in the same interval in which a QTL associated with resistance to soybean sudden death syndrome was identified. This interval is close to the one reported by Schuster et al. (2001) for resistance to SCN race 14.

In Brazil, to register and protect soybean cultivars, resistance to $\mathrm{SCN}$ races has to be reported in accordance with the classification proposed by Riggs \& Schmitt (1988). Most Brazilian cultivars show resistance only to races 1 and 3 . Although the latter causes most damage, 11 races of the pathogen have already been identified in several states (Dias et al., 2009).
Knowing the effects of and the relationship among QTLs associated with resistance to the various SCN races is fundamental for introgression of broad and specific resistance QTLs in elite cultivars. Thus, the identification of specific markers for resistance to different SCN races is necessary, since they are considered a convenient tool to identify race specific resistance in soybean lines. Other studies are needed to confirm and validate major and minor QTLs in various soybean sources, and a broader evaluation is especially necessary for soybean breeding programs in Brazil.

The objective of this work was to identify major and minor-effect QTLs for resistance to races 3, 9, and 14 of SCN in Hartwig soybean cultivar; to map new resistance QTLs for these races; and to check for the existence of epistatic interactions between QTLs.

\section{Materials and Methods}

A population of recombinant inbred lines (RIL) derived from the cross between cv. Hartwig (resistant) and line Y23 (susceptible) was evaluated for resistance to $\mathrm{SCN}$ races 3, 9, and 14. This population was developed from $\mathrm{F}_{2}$ plants obtained from five $\mathrm{F}_{1}$ plants, which were advanced in a greenhouse by the single seed descent method. Of these, 134 and 110 RILs $F_{6: 7}$ were evaluated for resistance to races 3 and 9, respectively, and 128 RILs were evaluated for resistance to race 14.

Inocula from races 3, 9, and 14 were kept in a susceptible cultivar - Embrapa 20 to race 3, Peking to race 9 , and Centeniall to race 14 - in a greenhouse at 25 to $30^{\circ} \mathrm{C}$. The quantity of cysts was increased for inoculation using the same cultivar. To evaluate the response of each SCN race, RIL population, parental lines, differentiating soybean lines ('Peking', 'Pickett', PI 90763, and PI 88788), and susceptible control ('Lee') were included in each experiment. The experiments were carried out in a completely randomized block design with three to six plants per treatment (RIL). The seeds were germinated in sand at $25^{\circ} \mathrm{C}$. Each plantlet, from two to three days of age, was transplanted into clay pots with a $0.5 \mathrm{~L}$ capacity, containing a mixture of soil and sand in the proportion of 1:2. Simultaneously to transplantation, each plant was inoculated with 4,000 SCN eggs. The inoculum was obtained from each susceptible cultivar. Plants were inoculated according to Dias et al. $(2005,2009)$, and maintained in a greenhouse $\left(25-30^{\circ} \mathrm{C}\right)$ with 16 hours of exposure 
to light. Thirty days after inoculation, plants were taken out of the pots and their roots were washed under a strong jet of water, over a 20 -mesh sieve, nested in a 60-mesh sieve. Cysts were counted under stereoscopic lens and transformed into an index of parasitism (IP), estimated by: IP $=100$ (number of cysts and females in a given plant/average number of cysts and females present in the susceptible parent). The susceptible parent was used in the denominator of the expression to evaluate the genetic differences between parents used in the cross. To confirm the SCN race, the IP was calculated by substituting the denominator of the expression by the number of cysts and females in Lee (susceptible standard cultivar), as proposed by Riggs \& Schmitt (1988).

DNA was extracted from soybean leaves of each RIL by the CTAB method (Keim et al., 1988), quantified in a spectrophotometer, and stored at $4^{\circ} \mathrm{C}$ until use. Six hundred SSR markers were evaluated in the parents, and 154 polymorphic microsatellites were used to genotype the population for linkage map construction. Amplification reactions were performed in a totalvolume of $15 \mu \mathrm{L}$, containing $10 \mathrm{mmol} \mathrm{L}^{-1}$ Tris- $\mathrm{HCl}, \mathrm{pH} 8.3$; $50 \mathrm{mmol} \mathrm{L} \mathrm{KCl}^{-1} ; 2.4 \mathrm{mmol} \mathrm{L}{ }^{-1} \mathrm{MgCl}_{2} ; 100 \mu \mathrm{mol} \mathrm{L}-1$ of each desoxinucleotide; $0.3 \mu \mathrm{mol} \mathrm{L}^{-1}$ of each primer; a unit of Taq-polymerase; and 30 ng genomic DNA. Amplification reactions were carried out in a Perkin Elmer 9600 thermocycler (Perkin Elmer, Norwalk, CA, USA) programmed for 30 cycles of $1 \mathrm{~min}$ at $94^{\circ} \mathrm{C}$, $1 \mathrm{~min}$ at $50^{\circ} \mathrm{C}$ and $2 \mathrm{~min}$ at $72^{\circ} \mathrm{C}$, and, at the end of the 30 cycles, $7 \mathrm{~min}$ at $72^{\circ} \mathrm{C}$. The amplification products were separated by electrophoresis in 3\% agarose gel or in $10 \%$ native vertical polyacrylamide gels, using a TAE $1 \mathrm{X}$ buffer $\left(0.09 \mathrm{~mol} \mathrm{~L}^{-1}\right.$ Tris-acetate and $0.002 \mathrm{~mol} \mathrm{~L}^{-1}$ EDTA). The gels were stained with ethidium bromide $\left(10 \mathrm{mg} \mathrm{mL}^{-1}\right)$ and photo documented.

Phenotype data obtained for each of the three races were analyzed with the Genes program (Cruz, 2006). The Lilliefors test for normality was performed for the three races, and normality was rejected. However, data transformation did not take place, and original data were used for all statistical analyses. This is a common procedure when evaluating resistant QTLs to SCN (Schuster et al., 2001; Guo et al., 2005; Wu et al., 2009). It is expected that the effect on the non-normality of the data will be significantly reduced by the use of co-factor markers (Zeng, 1994) and permutation tests to determine cut-off values (Churchill \& Doerge, 1994).
The estimation of QTL parameters in the GQMOL program uses multiple regression strategy instead of maximum likelihood; thus, data normality is not essential for the analysis (Cruz \& Schuster, 2004). Data were also submitted to analysis of variance (ANOVA) and estimation of genetic parameters. Treatment effects were considered to be random.

Heritability, $h^{2}(\%)$ was estimated by:

$$
h^{2}(\%)=\frac{\hat{\sigma}_{\mathrm{g}}^{2}}{\hat{\sigma}_{\mathrm{ph}}^{2}} \times 100,
$$

in which $\hat{\sigma}_{\mathrm{g}}^{2}$ and $\hat{\sigma}_{\mathrm{ph}}^{2}$ are the estimates of genetic and phenotypic variances, respectively.

The individual segregation of each marker was tested using the chi-square test in order to build the genetic map. Genetic distances between markers were established using minimum log of orders (LOD) score of 3.0, maximum recombination percentage of $30 \%$, Kosambi mapping function, and multilocus analysis in the GQMOL program (Cruz \& Schuster, 2010). LGs were designed according to the soybean consensus map (Song et al., 2004).

Co-segregation among markers in the population and phenotypic data of each RIL (mean IP) were analyzed by ANOVA single-marker analysis. QTL mapping was carried out using the composite interval method (Zeng, 1994). Additive effects, QTL determination coefficient, and the position of possible QTL were declared when the values of likelihood ratio (LR) were greater than the critical cutting values $(\alpha=0.05)$ in each LG. Critical LR values were determined by 1,000 permutations (Churchill \& Doerge, 1994). All analyses were carried out by the GQMOL program (Cruz \& Schuster, 2010). For epistatic analyses, the mixed model for composite interval mapping was applied in the QTLNetwork program (Yang et al., 2007). Levels of significance of candidate interval selection, putative QTL detection, and QTL effects were 0.05. The F test, based on Henderson method III, was used for hypothesis tests throughout the entire mapping procedure.

\section{Results and Discussion}

Significant genetic differences were detected within the population for each race (Table 1). Genetic variability in the parents was identified by the high variation of the average number of cysts among them, and by the detection of transgressive segregation in the population for the three races, evidencing effects of 
genetic and alelic interactions in the resistance control of these races. The minimum and maximum values of cysts in the populations were: 0.4 to 278.5 to race 3 ; 0.6 to 150.6 to race 9 ; and 0.0 to 351.6 to race 14 .

Estimates of hereditability varied from 34, 55 to $92 \%$ for races 9,3 , and 14 , respectively, indicating that there are genetic components conditioning resistance in this population (Table 1). In the crosses with PI 437654, hereditability, in the broad sense, was reported as $97 \%$ and $81 \%$ for resistance to race 3 (Webb et al., 1995; Wu et al., 2009), and as 54\% for race 14 (Wu et al., 2009). Schuster et al. (2001) observed strictsense heritability of $15 \%$ for race 14 in the 'Hartwig' $x$ BR-92-31983 cross.

Of 154 microsatellites amplified from a bulk of DNA of each RIL, ten had fixed alleles, most from cultivar Hartwig. This phenomenon was also observed by Yamanaka et al. (2001), and its genetic causes are still unknown. About $20 \%$ of the markers showed distortion of the Mendelian segregation expected for the population (1:1), which is frequent in several crops and has also been reported in soybean. In this study, markers with segregation distortion were kept in the LGs when they did not affect the order of the markers based on the soybean consensus linkage map (Song et al., 2004).

Eighty microsatellites were grouped into 22 LGs of the genome that represented genomic segments of 17 LGs of the soybean consensus linkage map (Song et al., 2004). Markers whose positions on the consensus map were not maintained were removed from the LGs. Many markers did not link to any LG, because of the great distances from the other markers in the same linkage group, or belonged to a LG that was not represented by any other marker, according

Table 1. Average number of cysts from soybean cyst nematode $(\mathrm{SCN})$ in the parents, and in the population of recombinant inbred lines (RIL) and statistical parameters.

\begin{tabular}{lccc}
\hline Variable & Race 3 & Race 9 & Race 14 \\
\hline Genotype & & & \\
'Hartwig' & 4.60 & 8.40 & 0.0 \\
Y23 & 39.33 & 59.25 & 275.17 \\
RIL & 90.59 & 35.89 & 174.28 \\
Statistic parameter ${ }^{(1)}$ & & & \\
$\quad$ Min - Max & $0.4-278.5$ & $0.6-150.6$ & $0.0-351.6$ \\
F value & $2.21^{* *}$ & $1.51^{* *}$ & $11.90^{* *}$ \\
$\mathrm{~h}^{2}$ & 54.87 & 33.74 & 91.59 \\
\hline
\end{tabular}

${ }^{(1)} \mathrm{h}^{2}(\%)$, heritability. ** Significant at $1 \%$ probability by the $\mathrm{F}$ test. to the consensus map. RIL populations have a large number of recombinants due to the successive cycles of meiosis; therefore, gene distances over $20 \mathrm{cM}$ might not be detected. Independently of whether the marker links to a LG or not, the association with resistance to the three races of SCN was evaluated for all markers by single-marker analysis (Liu, 1998).

Significant associations of 23 markers in seven LGs, eight markers in three LGs and five markers in four LGs for resistance to races 3, 9, and 14, respectively (Table 2), were verified by single-marker analysis. At $1 \%$ probability, nine markers were detected in LGs A2, $\mathrm{G}, \mathrm{J}$, and $\mathrm{K}$ for resistance to race 3, and one marker in $L G G$ for resistance to races 9 and 14. In $L G G$, a region associated with the three races was detected. Common regions for resistance to races 3 and 9 were identified in LGs G and J.

The marker Sat_141 in LG G was the only one with a highly significant association with the three races, and showed segregation distortion in the proportion of 2 susceptible: 1 resistant, in the three cases. This proportion was also observed for the markers Rhg4 (LG A2), Satt610 (LG G) and Satt499 (LG K) associated with race 3, and for the markers Satt376 (LG C2) and Satt082 (LG D2) associated with race 14 (Table 2). Glover et al. (2004) reported segregation distortion for marker Satt309, close to Sat_141, and for a marker close to a resistance QTL to races 3 and 14 in LG J, in crosses derived from PI 88788. The segregation distortion at locus rhgl was studied in $51 \mathrm{~F}_{4}$ populations and attributed to gamete selection, selection by abortion of seeds during development, and selection during seed emergence and development of the plant (Kopisch-Obuch \& Diers, 2006).

Using the composite interval method, four QTLs were detected for resistance to race 3 in LGs A2, G, $\mathrm{J}$, and $\mathrm{M}$, accounting for 12 to $34 \%$ of phenotypic variance (Table 3). A major QTL for resistance to race 9 was found in the same interval of the QTL for resistance to race 3 in LG G, while no QTL was detected for resistance to race 14 . Intervals with the highest LR values for race 14, but without significance, were observed in the LGs G and C2. The markers of these intervals were significant by single-marker analysis (Table 2).

Analysis of epistatic interactions can reveal QTLs that alone may not have any significant effect on the trait. Two pairs of epistatic interactions were detected 
for resistance to SCN races 9 and 14 (Table 4, Figure 1). The negative additive $\mathrm{x}$ additive effect indicates that the two epistatic loci with homozygous alleles from the resistant parent can reduce the number of females and cysts of SCN.

The QTL of LG G, interval Satt038/Satt275, which is common to resistance to races 3 and 9 , has already been reported in this population by Cervigni et al. (2007). In the present study, markers with significant associations for at least two races were found in the LG $\mathrm{G}$ in an extension of $23 \mathrm{cM}$ (Table 2), in accordance with the consensus map (Song et al., 2004). Six markers on LG G, Satt275, Sat_141, Satt235, Satt163, Satt038, and Satt309, covering about $5 \mathrm{cM}$ from the start of LG G, were associated to resistance to races 3 and 9. The marker Sat_141, located at about $10 \mathrm{cM}$ from the start of LG G, was highly significant for the three races (Table 2), whereas the interval Sat_141/

Table 2. Association analysis of markers for resistance to races 3, 9, and 14 of soybean cyst nematode (SCN) in recombinant inbred lines derived from the 'Hartwig' x Y23 cross.

\begin{tabular}{|c|c|c|c|c|c|c|c|}
\hline Race of SCN & Marker & $\mathrm{LG}$ & $\mathrm{P}^{(1)}$ & 'Hartwig' & Y23 & Position $^{(2)}$ & SD \\
\hline \multirow[t]{23}{*}{ Race 3} & Sat_162 & A2 & $0.039 *$ & 120.58 & 158.56 & 51.51 & - \\
\hline & Sat_157 & $\mathrm{A} 2$ & $0.009^{* *}$ & 104.60 & 153.86 & 51.6 & - \\
\hline & Rhg4 & $\mathrm{A} 2$ & $0.029 *$ & 111.11 & 153.97 & 58.4 & (71S:36R) \\
\hline & Satt632 & $\mathrm{A} 2$ & $0.014 *$ & 111.66 & 157.95 & 51.57 & - \\
\hline & Satt342 & D1a & $0.030^{*}$ & 159.13 & 120.03 & 48.1 & - \\
\hline & Sat_163 & $\mathrm{G}$ & $0.038^{*}$ & 115.04 & 153.66 & 10.1 & - \\
\hline & Satt275 & G & $0.000 * *$ & 82.65 & 177.89 & 2.2 & - \\
\hline & Sat_141 & G & $0.006^{* *}$ & 105.89 & 157.32 & 9.18 & $(81 \mathrm{~S}: 45 \mathrm{R})$ \\
\hline & Satt610 & G & $0.037 *$ & 96.88 & 167.05 & 10.92 & $(50 \mathrm{~S}: 22 \mathrm{R})$ \\
\hline & Satt217 & G & $0.005^{* *}$ & 115.41 & 167.14 & 18.25 & - \\
\hline & Satt130 & G & $0.036^{*}$ & 113.65 & 162.29 & 23.1 & - \\
\hline & Satt235 & G & $0.017^{*}$ & 114.13 & 159.73 & 21.89 & - \\
\hline & Satt163 & G & $0.001 * *$ & 107.90 & 169.22 & 0.0 & - \\
\hline & Satt038 & G & $0.000^{* *}$ & 94.86 & 185.86 & 1.84 & - \\
\hline & Satt309 & G & $0.023 *$ & 117.98 & 162.37 & 4.53 & - \\
\hline & Satt142 & $\mathrm{H}$ & $0.035^{*}$ & 118.44 & 157.34 & 86.49 & - \\
\hline & Satt353 & $\mathrm{H}$ & $0.042 *$ & 156.43 & 118.69 & 8.48 & - \\
\hline & Satt456 & $\mathrm{J}$ & $0.004^{* *}$ & 166.61 & 123.55 & 40.83 & - \\
\hline & Satt215 & $\mathrm{J}$ & $0.009^{* *}$ & 165.88 & 117.61 & 44.08 & - \\
\hline & Satt499 & K & $0.018^{*}$ & 120.77 & 159.42 & 71.01 & - \\
\hline & Satt242 & $\mathrm{K}$ & $0.025^{*}$ & 149.86 & 141.00 & 14.35 & (71S:43R) \\
\hline & Satt551 & M & $0.026^{*}$ & 159.38 & 115.26 & 95.4 & - \\
\hline & Satt250 & $\mathrm{M}$ & $0.048^{*}$ & 155.70 & 118.77 & 107 & - \\
\hline \multirow[t]{8}{*}{ Race 9} & Satt556 & B2 & $0.027^{*}$ & 42.12 & 76.98 & 78.6 & - \\
\hline & Satt275 & G & $0.023 *$ & 43.08 & 75.70 & 2.2 & - \\
\hline & Sat_141 & G & $0.023^{*}$ & 44.28 & 68.47 & 9.18 & $(66 \mathrm{~S}: 39 \mathrm{R})$ \\
\hline & Satt235 & G & $0.038 *$ & 46.42 & 69.77 & 21.89 & - \\
\hline & Satt163 & G & $0.032 *$ & 46.16 & 69.75 & 0.0 & - \\
\hline & Satt038 & G & $0.000^{* *}$ & 41.10 & 80.93 & 1.84 & - \\
\hline & Satt309 & G & $0.009^{* *}$ & 45.84 & 76.71 & 4.53 & - \\
\hline & Satt456 & $\mathrm{J}$ & $0.0231 *$ & 48.05 & 71.42 & 40.83 & - \\
\hline \multirow[t]{5}{*}{ Race 14} & Satt376 & $\mathrm{C} 2$ & $0.010^{*}$ & 55.72 & 67.84 & 97.8 & (71S: 2R) \\
\hline & Satt370 & D1a & $0.027 *$ & 66.37 & 53.09 & 50.16 & - \\
\hline & Satt082 & D2 & $0.032 *$ & 57.58 & 69.66 & 87.2 & (47S:70R) \\
\hline & Sat_141 & G & $0.009 * *$ & 54.45 & 68.81 & 9.18 & $(72 \mathrm{~S}: 52 \mathrm{R})$ \\
\hline & Satt038 & G & $0.051^{*}$ & 57.88 & 69.63 & 1.84 & - \\
\hline
\end{tabular}

${ }^{(1)}$ Contrast of averages between alleles from 'Hartwig' and Y23. ${ }^{(2)}$ Position according to consensus map (Song et al., 2004). LG, linkage group. SD, segregation distortion. ** and *Significant at 1 and $5 \%$ probability by the $t$ test. 
Satt610 showed epistastic effect with the interval Satt142/Satt302 in LG H for resistance to race 14 (Figure 1). The Satt217/Satt235 interval in LG G, with positions on the consensus map of 18.25 and $21.89 \mathrm{cM}$, respectively, was epistatic with the interval in LG D2 for resistance to race 9. The marker Satt 235 had significant association for resistance to races 3 and 9 . These results indicate that a similar interval is significant for all three races and that the rhgl is the major resistance gene in this LG, conferring resistance, although with some specificities. According to Concibido et al. (2004), besides the rhgl gene, another three loci in LG G were associated with resistance to SCN race 3, detected in the sources of resistance 'Peking', PI 438489B and PI 468916, which indicates possible rearrangements of resistance genes in this LG.

Regarding races 9 and 14, a greater number of genomic regions was identified for resistance to race 3 , whether by single-marker analysis ( 23 markers in seven linkage groups: A2, D1a, G, H, J, K, and M) or by composite interval mapping (four QTLs in LG A2, $\mathrm{G}, \mathrm{J}$, and M). Wu et al. (2009) also observed a greater number of QTLs for resistance to race 3 than for races 1 ,

Table 3. Quantitative trait loci (QTL) for resistance to races 3,9 , and 14 of soybean cyst nematode in a population of recombinant inbred lines derived from the 'Hartwig' $\mathrm{x}$ Y23 $\operatorname{cross}^{(1)}$.

\begin{tabular}{lccccc}
\hline Race & LG & Interval & LR & $\mathrm{R}^{2}(\%)$ & Additive effect \\
\hline 3 & A2 & Sat_157/Rhg4 & $13.85^{* *}$ & 12.9 & -38.82 \\
& G & Satt038/Satt275 & $31.53^{* *}$ & 34.8 & -66.91 \\
& J & Sat_366/Satt215 & $16.35^{* *}$ & 17.7 & -37.12 \\
& M & Satt250/Satt551 & $13.39^{* *}$ & 15.5 & 36.97 \\
9 & G & Satt038/Satt275 & $15.08^{*}$ & 22.2 & -27.20 \\
14 & C2 & Satt316/Satt202 & $6.75^{\text {ns }}$ & 5.9 & -7.43 \\
& G & Sat_163/Sat_141 & $7.27^{\text {ns }}$ & 5.6 & -7.31 \\
\hline
\end{tabular}

(1)LG, linkage group. LR, likelihood ratio values exceeded the critical cut-off values, determined by 1,000 permutations. $\mathrm{R}^{2}$, coefficient of deter-

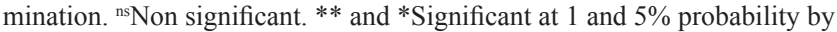
the $\mathrm{F}$ test, respectively, in each linkage group.
2, 5, and 14 in a population derived from PI 437654. Kazi et al. (2010) verified the same situation for race 3 in relation to races 2 and 14 , in a population derived from 'Hartwig'. The greatest number of QTLs detected for resistance to race 3 in a population in which other races are also evaluated indicates greater complexity in the resistance mechanisms for this race. Various studies on several sources of resistance report resistance QTLs to race 3 in 13 of the $20 \mathrm{LGs}$ of soybean, A2, B1, B2, C1, C2, D1a, E, F, G, H, I, J, and M (Concibido et al., 2004; Wu et al., 2009).

The genomic regions detected for the QTLs in LGs $\mathrm{A} 2$ and $\mathrm{G}$ indicate that these correspond to genes Rhg4 and $r h g 1$, respectively, already widely reported and characterized for resistance to race 3 (Concibido et al., 2004; Winter et al., 2006; Cervigni et al., 2007). The QTL detected in LG A2 was only associated with resistance to race 3. This QTL has been reported to be associated with resistance to races 1 and 3 of SCN in studies of a single population evaluated for response to several SCN races (Concibido et al., 2004; Wu et al., 2009). Webb et al. (1995) and Wu et al. (2009) identified this QTL at PI 437654. The QTL in LG $\mathrm{G}$ has been identified by Cervigni et al. (2007) as a major resistance factor for races 3 and 9 using this population.

The QTL in LG J, detected in the interval Sat_366/ Satt215, explained $17.7 \%$ of phenotypic variance for resistance to race 3 (Table 3). Satt456, close to this interval, according to the consensus map, showed significant association with resistance to races 3 and 9. Guo et al. (2005) reported a QTL in LG J associated with resistance to races 2 and 3 in the interval Satt547/ Sat 224 at PI 90763, located at 67.7 and $75.1 \mathrm{cM}$, respectively, in the consensus map. Glover et al. (2004), in crosses with PI 88788, confirmed a resistance QTL to race 14 close to marker Satt431, located at $78.5 \mathrm{cM}$ in the consensus map. The markers described for resistance in these two studies are found in regions that

Table 4. Epistatic interactions between different quantitative trait loci (QTL) for resistance to races 9 and 14 of soybean cyst nematode in a population of recombinant inbred lines derived from the 'Hartwig' x Y23 cross $^{(1)}$.

\begin{tabular}{ccccccccc}
\hline Race & LG & Interval_i & Size_i $(\mathrm{cM})$ & LG & Interval_j & Size_j $(\mathrm{cM})$ & Epistatic effect $\mathrm{x}$ additive effect & P value \\
\hline 9 & G & Satt235/Satt217 & $24.9-34.8$ & D2 & Satt574/Satt528 & $5.0-11.7$ & -20.0631 \\
14 & G & Sat_141/Satt610 & $48.0-57.4$ & H & Satt142/Satt302 & $5.0-22.9$ & -10.1456 & 0.000069 \\
\hline
\end{tabular}

${ }^{(1)} \mathrm{cM}$, centimorgans; LG, linkage group; interval_i, the flanking markers of QTL_i; interval_j, the flanking markers of QTL_j (QTL_i and QTL j, the two QTL involved in epistatic interaction); size_ $i$, interval of QTL_i in cM; size $\_j$, interval of $Q T L \_j$ in $c M$. 
are close to each other in the LG; however, the QTL detected in the present study is in a region far from both of them ( $40.8 \mathrm{cM}$ to $44.0 \mathrm{cM}$ in the consensus map), which indicates that this is a new region associated with resistance in this $L G$.

The QTL detected in LG M, at interval Satt250/ Satt551, showed positive additive effect (Table 4). This fact, associated with the result of the comparison between individual averages from individuals with the alleles of each parent for these markers (Table 2), indicates the presence of a QTL for susceptibility in this region. Therefore, the average number of genotypes with a resistant parent's allele was greater than the number with a susceptible allele. Thus, the selection should be carried out against the allele of the resistant parent.

Markers associated with resistance to race 3 have been reported in LG K, in Satt499 and Satt242. Although the marker Satt499 did not link to any other markers of this $\mathrm{LG}$, due to the great genomic distance in the consensus map, this result confirmed the presence of a resistance region to SCN in LG K. Wu et al. (2009) were the first to report a low-effect resistance QTL to race 1 at the Satt499/Satt552 interval in a study with PI 437654.

A major-effect QTL for resistance to race 9, detected in the Satt038/Satt275 interval in LG G, has already been identified by Cervigni et al. (2007). There are no other publications in the literature reporting QTLs for this race. Significant associations between resistance to race 9 with markers from LGs B2 (Satt556) and J (Satt456) reveal that, in this population, other low-effect regions are involved in the control of resistance for

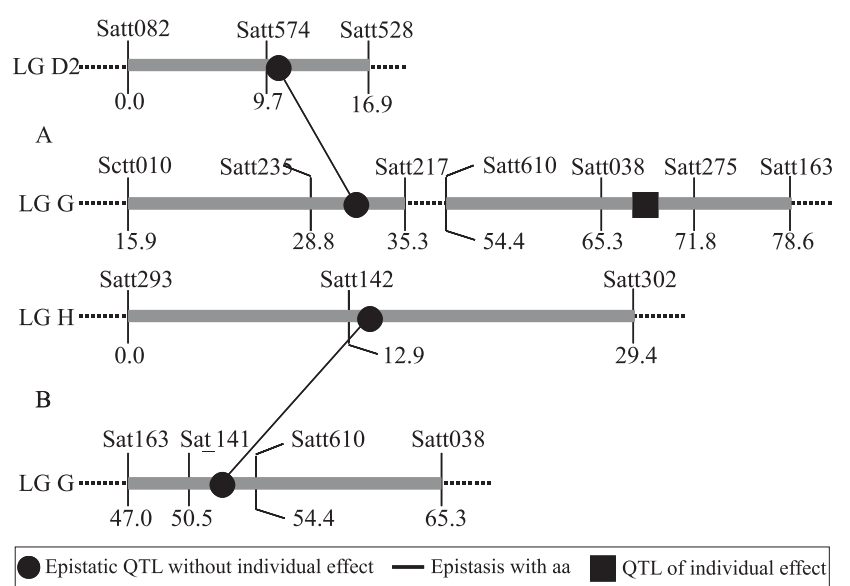

Figure 1. Intervals in linkage groups with quantitative trait loci (QTL) and epistatic interactions to soybean cyst nematode $(\mathrm{SCN})$ resistance to races $9(\mathrm{~A})$ and $14(\mathrm{~B})$. this race. The marker Satt456 was also significantly associated with resistance to race 3 . A significant epistatic interaction was detected between the regions of the Satt235/Satt217 (LG G) and Satt574/528 (LG D2) intervals, with high negative epistatic aa effect, indicating the presence of QTLs that are important for resistance to race 9, which were not detected by composite interval analysis (Table 4, Figure 1). The interval of LG G, at Satt235/Satt217, is distant from the QTL reported by Cervigni et al. (2007) in this population, indicating another region for resistance to race 9 in this LG. The interval of LG D2 is close to the resistance QTL to race 14 found by Schuster et al. (2001) in a cross with cultivar Hartwig. Kazi et al. (2010) recently reported the importance of this region in LG D2 for resistance to race 2.

For resistance to race 14, five markers in LGs C2, D1a, D2, and G showed significant associations. Of these, three showed segregation distortion. Two markers from LG G had significant associations for resistance to two other races (Table 2). The highest values of LR were detected for intervals with markers Sat 141 (LG G) and Satt202 (LG C2) by composite interval analysis, but were not considered significant (Table 3). A significant epistatic interaction was found between the intervals of Sat_141/Satt610 and Satt142/Satt302 in LG H (Figure 1) using mixed model analysis. In the literature, QTLs for resistance to race 14 were found in LGs B1, C1, C2, D1a, D2, E, G, J, and M, in various sources (Wang et al., 2001; Concibido et al., 2004). In PI 437654, a low-effect QTL was found in LG I (Wu et al., 2009).

In LG D2, Satt082 had significant association with resistance (Table 2), which indicates that this region has low-effect resistance to race 14 in this population. In the interval Satt082/Satt574, Schuster et al. (2001) also detected a major-effect QTL in a population derived from a cross with 'Hartwig'. Kazi et al. (2010) detected a resistance QTL to race 2 in marker Satt574, near the interval Satt082, in 'Hartwig'. Differences in the magnitude of the effects of a QTL are expected, since the detection of QTLs may be influenced by the type of population, genetic background, QTL magnitude, and environmental effects. Regarding the low-effect QTL mapped in LG C2 at Satt376 (located at $97.8 \mathrm{cM}$ in the consensus map) by single-marker analysis, Glover et al. (2004) detected, near this region, an association of resistance to races 3 and 14 with Satt 277 (at $107 \mathrm{cM}$ on the consensus map) in crosses with PI 88788. 
In this study, composite interval analysis did not detect QTL for resistance to race 14 in LG G. However, Sat_141, located in this group, was significant and showed epistatic interaction with an interval of LG $\mathrm{H}$ of low and negative aa effect (Table 4). This indicates that, in LG G, minor-effect QTLs contribute to resistance to race 14 in this population. Kazi et al. (2010) reported a QTL in LG G for resistance to this race in 'Hartwig'. Glover et al. (2004) also detected a QTL in LG G in crosses with PI 88788, near rhg1, for races 3 and 14 .

The importance of a wide region in $L G$ for resistance to $\mathrm{SCN}$ and for assisted selection are indicated by the presence of a resistance QTL common to races 3 and 9 in the interval Satt038/Satt275 from LG G, by: a highly significant association of Sat_141 with resistance to the three races, the epistatic interaction of the interval Satt235/217 for resistance to race 9, the epistatic interaction of Sat_141/Satt610 interval for resistance to race 14 , and the fact that all these markers are less than $20 \mathrm{cM}$ apart on the consensus map (Song et al., 2004). These results indicate that, in the case of races 3 and 9, resistance is given by a major gene in LG G, and that other low-effect genes in other LGs are responsible for race specificity. For race 14, minor-effect genes may also be involved. The results of the present study, in comparison to the literature, show the influence of genetic background in allelic interactions, as well as the key effect of LG $\mathrm{G}$ on resistance to the three races evaluated, and the importance of minor-effect genes for each race.

\section{Conclusions}

1. There are high and low-effect resistance QTLs to soybean cyst nematode in Hartwig cultivar.

2. Additive epistatic interactions for races 9 and 14 are verified, and new regions of low-effect for resistance are reported.

3. Quantitative variation for resistance to soybean cyst nematode includes loci with additive and epistatic effect, which may be dependent on SCN race.

\section{Acknowledgments}

To Conselho Nacional de Desenvolvimento Científico e Tecnológico and to Coordenação de Aperfeiçoamento de Pessoal de Nível Superior, for scholarships granted.

\section{References}

BRUCKER, E.; CARLSON, S.; WRIGHT, E.; NIBLACK, T.; DIERS, B. Rhgl alleles from soybean PI 437654 and PI 88788 respond differentially to isolates of Heterodera glycines in the greenhouse. Theoretical and Applied Genetics, v.111, p.44-49, 2005.

CERVIGINI, G.D.L.; SCHUSTER, I.; SILVA, M.F.; SEDIYAMA, C.S.; BARROS, E.G. de; MOREIRA, M.A. A common QTL for resistance to races 3 and 9 of soybean cyst nematode. Revista de la Facultad de Agronomía, v.106, p.137-144, 2007.

CHURCHILL, G.A.; DOERGE, R.W. Empirical threshold values for quantitative trait mapping. Genetics, v.138, p.963-971, 1994.

CONCIBIDO, V.C.; DIERS, B.W.; ARELLI, P.R. A decade of QTL mapping for cyst nematode resistance in soybean. Crop Science, v.44, p.1121-1131, 2004.

CRUZ, C.D. Programa Genes: estatística experimental e matrizes. Viçosa: UFV, 2006. 285p.

CRUZ, C.D.; SCHUSTER, I. GQMOL: aplicativo computacional para análise de dados moleculares e de suas associações com caracteres quantitativos. Versão 2.1. Viçosa: UFV, 2004. Disponível em: <www.ufv.br/dbg/gqmol/gqmol.htm>. Acesso em: 02 nov. 2010.

DIAS, W.P.; CAMPOS, V.P.; ARIAS, C.A.A.; KIIHL, R.A.S.; TOLEDO, J.F.F. Genetic control in soybean of resistance to soybean cyst nematode race 4+. Euphytica, v.145, p.321-329, 2005.

DIAS, W.P.; SILVA, J.F.V.; CARNEIRO, G.E.S.; GARCIA, A.; ARIAS, C.A.A. Nematóide de cisto da soja: biologia e manejo pelo uso da resistência genética. Nematologia Brasileira, v.33, p.1-16, 2009.

GLOVER, K.D.; WANG, D.; ARELLI, P.R.; CARLSON, S.R.; CIANZIO, S.R.; DIERS, B.W. Near isogenic lines confirm a soybean cyst nematode resistance gene from PI 88788 on linkage group J. Crop Science, v.44, p.936-941, 2004.

GUO, B.; SLEPER, D.A.; ARELLI, P.R.; SHANNON, J.G.; NGUYEN, H.T. Identification of QTLs associated with resistance to soybean cyst nematode races 2, 3 and 5 in soybean PI 90763. Theoretical and Applied Genetics, v.111, p.965-971, 2005.

GUO, B.; SLEPER, D.A.; NGUYEN, H.T.; ARELLI, P.R.; SHANNON, J.G. Quantitative trait loci underlying resistance to three soybean cyst nematode populations in soybean PI 404198A. Crop Science, v.46, p.224-233, 2006.

KAZI, S.; SHULTZ, J.; AFZAL, J.; HASHMI, R.; JASIM, M.; BOND, J.; ARELli, P.R.; LIGHTFOOT, D.A. Iso-lines and inbred-lines confirmed loci that underlie resistance from cultivar 'Hartwig' to three soybean cyst nematode populations. Theoretical and Applied Genetics, v.120, p.633-644, 2010.

KEIM, P.; OLSEN, T.C.; SHOEMAKER, R.C. A rapid protocol for isolating soybean DNA. Soybean Genetics Newsletter, v.15, p.147-148, 1988.

KOPISCH-OBUCH, F.J.; DIERS, B.W. Segregation at the SCN resistance locus rhgl in soybean is distorted by an association between the resistance allele and reduced field emergence. Theoretical and Applied Genetics, v.112, p.199-207, 2006. 
LIU, H.B. Statistical genomics: linkage, mapping and QTL analysis. Boca Raton: CRC Press, 1998. 611p.

NIBLACK, T.L.; ARELLI, P.R.; NOEL, G.R.; OPPERMAN, C.H.; ORF, J.H.; SCHMITT, D.P.; SHANNON, J.G.; TYLKA, G.L. A revised classification scheme for genetically diverse populations of Heterodera glycines. Journal of Nematology, v.34, p.279-288, 2002.

RIGGS, R.D.; SCHMITT, D.P. Complete characterization of the race scheme for Heterodera glycines. Journal of Nematology, v.20, p.392-395, 1988 .

SCHUSTER, I.; ABDELNOOR, R.V.; MARIN, S.R.R.; CARVALHO, V.P.; KIIHL, R.A.S.; SILVA, J.F.V.; SEDIYAMA, C.S.; BARROS, E.G.; MOREIRA, M.A. Identification of a new major QTL associated with resistance to soybean cyst nematode (Heterodera glycines). Theoretical and Applied Genetics, v.102, p.91-96, 2001.

SONG, Q.J.; MAREK, L.F.; SHOEMAKER, R.C.; LARK, K.G.; CONCIBIDO, V.C.; DELANNAY, X.; SPETCH, J.E.; CREGAN, P.B. A new integrated genetic linkage map of the soybean. Theoretical and Applied Genetics, v.109, p.122-128, 2004.

VIERLING, R.A.; FAGHIHI, J.; FERRIS, V.R.; FERRIS, J.M. Association of RFLP markers conferring broad-based resistance to the soybean cyst nematode (Heterodera glycines). Theoretical and Applied Genetics, v.92, p.83-86, 1996.

WANG, D.; ARELLI, P.R.; SHOEMAKER, R.C.; DIERS, B.W. Loci underlying resistance to race 3 of soybean cyst nematode in
Glycine soja plant introduction 468916. Theoretical and Applied Genetics, v.103, p.561-566, 2001.

WEBB, D.M.; BALTAZAR, B.M.; RAO-ARELLI, A.P.; SCHUPP, J.; CLAYTON, K.; KEIM, P.; BEAVIS, W.D. Genetic mapping of soybean cyst nematode race-3 resistance loci in the soybean PI 437654. Theoretical and Applied Genetics, v.91, p.574-581, 1995.

WINTER, S.M.J.; RAJCAN, I.; SHELP, B.J. Soybean cyst nematode: challenges and opportunities. Canadian Journal of Plant Science, v.86, p.25-32, 2006.

WU, X.; BLAKE, S.; SLEPER, D.A.; SHANNON, J.G.; CREGAN, P.; NGUYEN, H.T. QTL, additive and epistatic effects for SCN resistance in PI 437654. Theoretical and Applied Genetics, v.118, p.1093-1105, 2009.

YAMANAKA, N.; NINOMIYA, S.; HOSHI, M.; TSUBOKURA, Y.; YANO, M.; NAGAMURA, Y.; SASAKI, T.; HARADA, K. An informative linkage map of soybean reveals QTLs for flowering time, leaflet morphology and regions of segregation distortion. DNA Research, v.8, p.61-72, 2001.

YANG, J.; ZHU, J.; WILLIAMS, R.W. Mapping the genetic architecture of complex traits in experimental populations. Bioinformatics, v.23, p.1527-1536, 2007.

ZENG, Z.B. Precision mapping of quantitative trait loci. Genetics, v.136, p.1457-1468, 1994.

Received on November 16, 2010 and accepted on March 14, 2011 